\title{
The Rhetoric of Agitation and Control: Impact in Scholarly Works
}

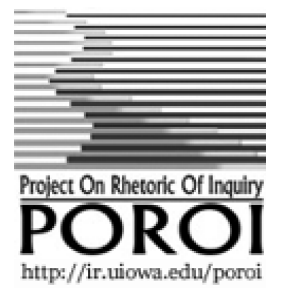

\author{
Jaqueline J. Schmidt \\ John Carroll University \\ University Heights, Ohio USA
}

Poroi 9,2 (August 2013)

The fall of 1969 was a time of great political unrest in the United States. The war in Vietnam raged on and many college campuses including the University of Iowa were the site of protests or questioning. This was the scene as I entered the graduate program in Communication Studies at the University of Iowa. I began by taking the regular schedule of courses following a then traditional rhetorical studies program. However, in the spring of my first year (1970), I was attracted to a course in rhetoric taught by Donovan Ochs that among other theories examined social movements. While I had studied rhetorical criticism before, it was in this course that I began to look at rhetorical analysis in a different light. Donovan Ochs and John Bowers devised selected cases to use as a framework to consider movements instead of analyzing one speech or a series of speeches by one person. We looked at movements involving several speakers and even other media to examine and evaluate the actions of both sides of an issue (agitation and control). In this analysis I not only saw a new approach to criticism, but also the collaboration of two great scholars, one from rhetorical theory and one from communication theory. Their collaboration taught me a life-long lesson to value the interaction of scholarship within and across disciplines. It was exciting. As John Bowers describes in his contribution to this volume, this framework and these cases were to become part of the first edition of The Rhetoric of Agitation and Control by Bowers and Ochs published in 1971. The text was revised in 1993 by Bowers, Ochs, and Jensen and is now in its third edition in 2010 with Bowers, Ochs, Jensen, and Schulz. What is the impact of this text which has continued to be used and revised over a forty year period?

There are several ways to assess the importance or impact of a work. In this paper I address impact by examining the number of times The Rhetoric of Agitation and Control has been referred to in scholarly works. This study covers the period from 1971 to September 2012 and uses Google Scholar as the database. Citations were analyzed to determine the number of works that cited The Rhetoric of Agitation and Control, the types of publications, the general theme of the scholarly work in which the reference was made, and how the text has been used.

As of September 2012 Google Scholar listed 186 citations of The Rhetoric of Agitation and Control. Table 1 shows the division of these references in terms of journals, textbooks, dissertations/theses/papers and other sources. This list is of scholarly works only and does not include listings in syllabi or blogs on the internet. 


\section{Types of Publication}

Journals

Communication

\section{Publication Name}

\section{\# of Citations}

\section{9}

87

Communication Studies (formerly

Central States Speech Journal)

Quarterly Journal of Speech

Southern Communication Journal

(formerly Southern Speech

Communication Journal)

Communication Quarterly

Communication Monographs

6

Western Journal of Communication

(formerly Western Journal of

Speech Communication)

6

Rhetoric Society Quarterly 2

Critical Discourse Studies

1

Rhetoric and Public Affairs 1

Small Group Research 1

Communication Education 2

Women's Studies in Communication 1

Critical Studies in Media

Communication

1

Communication and

Critical/Cultural Studies

1

Journal of Applied Communication Research

1

Visual Communication Quarterly 1

Journalism Studies 1

Howard Journal of Communication 1

Communication Research Reports 1

Communication Theory 1

Speaker and Gavel 1

Argumentation 1

Journal of Communication Inquiry 1

Cultural Studies/Critical

Methodologies 


\section{Types of Publication}

Publication Name

\section{\# of Citations}

Management

4

Management Communication

Quarterly

2

Journal of Communication

Management

1

Journal of Business Communication $\quad 1$

International

\section{6}

Mobilization: An International

Quarterly

Philippine Quarterly of Culture and

Society

International Communication

Gazette

1

International Journal of Comic Art 1

Culture/ Sociology

Public Administration Review 1

American Sociological Review 1

Social Service Review 1

Expert Systems 1

Social Problems 1

Journal of Black Studies 1

Journal of Language and Social

Psychology 1

Journal of Nonprofit \& Public Sector

Marketing

\section{1}

Other

The Environmental Communication

Yearbook

Journal of Park and Recreation

Administration

Review of Religious Research

Sociology of Religion: A Quarterly

Review

College of English 1

Journal of Language and Politics 1

Politico 1

Popular Music and Society 1 


\begin{tabular}{|c|c|c|}
\hline Types of Publication & Publication Name & \# of Citations \\
\hline & $\begin{array}{l}\text { Scholarship and Professional Work: } \\
\text { Communication }\end{array}$ & 1 \\
\hline & Explorations in Media Ecology & 1 \\
\hline & JAC Online & 1 \\
\hline & Archival Science & 1 \\
\hline Textbooks & & 28 \\
\hline & Communication & 21 \\
\hline & Research Methods & 2 \\
\hline & Political Science/Communication & 1 \\
\hline & Sociology & 1 \\
\hline & Activism and Rhetoric & 1 \\
\hline & Conflict and Diversity & 1 \\
\hline & Social Movement & 1 \\
\hline Studies, Essays and Other & & 39 \\
\hline & Dissertation & 21 \\
\hline & Thesis & 10 \\
\hline & Faculty Fellow Paper & 1 \\
\hline & Conference Paper & 1 \\
\hline & Book & 3 \\
\hline & $\begin{array}{l}\text { Sage Annual Reviews of } \\
\text { Communication Research }\end{array}$ & 1 \\
\hline & Communication Essay Collection & 1 \\
\hline & Directory & 1 \\
\hline TOTAL & & 186 \\
\hline
\end{tabular}

Table 1 - Citations

The largest number of citations is in journals, particularly communication journals. The Rhetoric of Agitation and Control has been cited a total of eighty-seven times in twenty-four different communication journals. It is cited most often in Communication Studies (formerly the Central States Communication Journal), 19, the Quarterly Journal of Speech, 15, and The Southern Communication Journal (formerly Southern Speech Communication Journal), 12 times. However, the impact of the text has gone beyond the field of communication to include journals from management, international culture, sociology, religion, environment and other fields. The text is referred to a total of thirty-two times in twentyseven journals outside of the communication discipline.

The text is also referred to in textbooks both in the field of communication, in areas such as persuasion, conflict, public relations, 
and in the fields of sociology and political science. The Rhetoric of Agitation and Control has also been referenced in thirty-one dissertations or master's theses and in several papers and collections.

These references are spread over the forty years and three editions of the text, as table 2 illustrates. In fact, references by scholars to the text appear to be increasing over time showing that the text continues to be valuable to research.

\begin{tabular}{|l|l|}
\hline Decade & Citations \\
\hline $1970-79$ & 30 \\
\hline $1980-89$ & 31 \\
\hline $1990-99$ & 37 \\
\hline $2000-09$ & 72 \\
\hline $2010-2012$ & 16 \\
\hline
\end{tabular}

Table 2 - Citations by Decade

An examination of the works in which the text is cited reveals the following breakdown of general themes.

\begin{tabular}{|l|l|}
\hline Reference Theme & Reference Type \\
\hline Communication Research & 2 \\
\hline Conflict & 6 \\
\hline Management & 1 \\
\hline Media & 7 \\
\hline Movements and Social Movement Theory & 111 \\
\hline Music & 5 \\
\hline Persuasion & 4 \\
\hline Political Campaign & 14 \\
\hline Power & 2 \\
\hline Rhetorical Theory/Criticism & 34 \\
\hline Total & $\mathbf{1 8 6}$ \\
\hline
\end{tabular}

Table 3 - Themes 


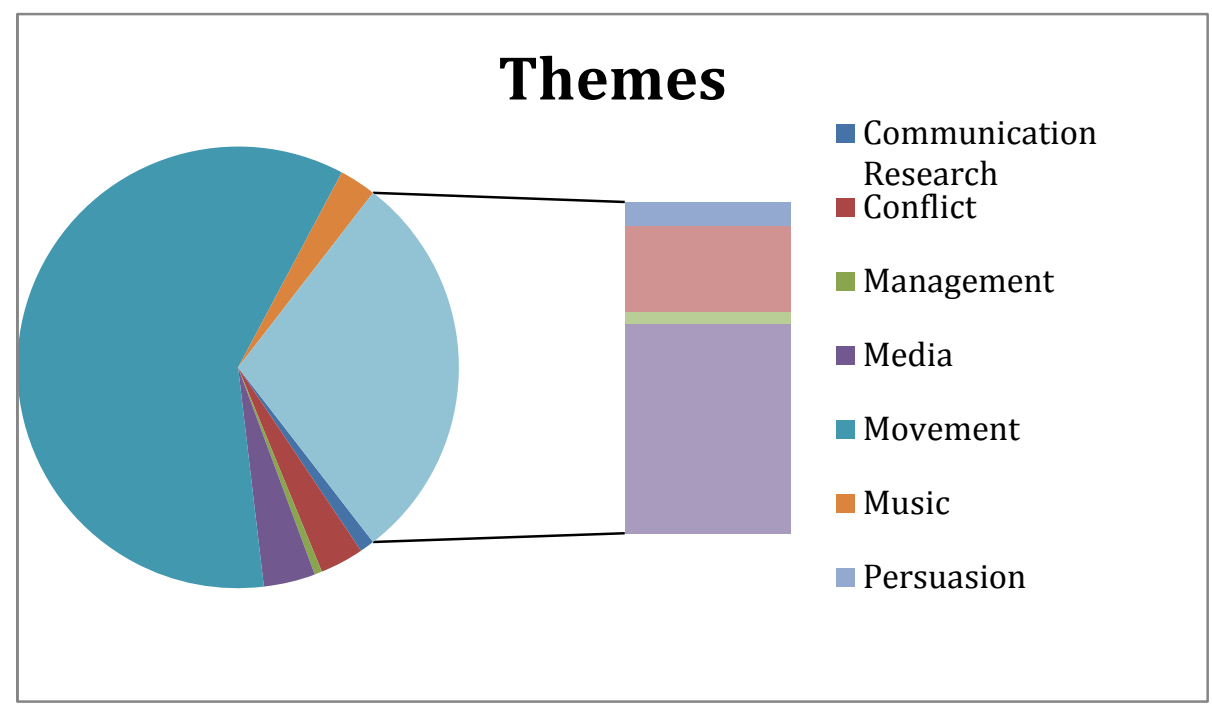

The most frequent themes in works citing The Rhetoric of Agitation and Control are the study of specific social movements, social movement theory and rhetorical theory. As Table 4 illustrates, the types of social movement studies citing the text also vary. This shows that the study of movement has become over time a field or at least a subfield in which Bowers and Oaks have a classic status

\section{Social Movement Theory \& Individual Movements}

American Revolution

Animal Rights

Asian-American

1

Civil Rights

$\begin{array}{ll}\text { Black Power } & 5 \\ \text { General } & 7 \\ \text { Hate Groups } & 1 \\ \text { Presidency } & 1 \\ \text { Social Control } & 1 \\ \text { Race } & 2\end{array}$

Cold War

1

Communism

Community Programs

Conservative

Consumer 


\section{Social Movement Theory \& Individual Movements}

DeafCulture 1

$\begin{array}{ll}\text { Environment } & 6\end{array}$

Filipino-American 2

Garbage 1

Homosexuality 1

Humane society 1

Immigration 2

Israeli 2

Labor 9

Latino 1

Maoist Insurgence 1

Native Americans 4

Obesity 1

Outdoor recreation education 1

Outsourcing (India) 1

Philippine 1

Rastafarian $\quad 2$

Religion

$\begin{array}{ll}\text { Catholic } & 2 \\ \text { Christian } & 1 \\ \text { Evangelical } & 2 \\ \text { Mormon } & 3\end{array}$

Russia
3

Sanctuary

Sanitation Strike

Sexism

Social Action

Social Movement Theory

STDs

Vietnam

Women's Movement

Youth Movement

1

1

6

2

1

1

1

2

2

9

1

1

4

1

1

1

1

\section{Total} Table 4 - Types of Social Movement Studies 
A closer examination of the references shows the text has been used in several ways by scholars. It has served as a model of social movement and rhetorical criticism. Rybacki and Rybacki in Communication Criticism: Approaches and Genres (1991) and Frey, Botan, and Kreps in Investigating Communication: An Introduction to Research Methods (2000) refer to The Rhetoric of Agitation and Control as an example of both social movement and historical criticism. In Persuasion in the Media Age (2002), Borchers uses The Rhetoric of Agitation and Control (second edition) as a model to examine strategies by agitators and those in control in his chapter on persuasive movements. While describing an example of conflict escalation at the University of Buffalo in their book Social Conflict, Rubin, Pruitt and Kim suggest that "those who want to understand the surprisingly consistent pattern of this pas de deux should read The Rhetoric of Agitation and Control" (1994, 92).

The book has also served as model for scholars examining specific social movements. Saunders uses the model to "measure intergroup communication" in her analysis of the Eastern Airline's crisis (Millar and Heath, 2004). Brimeyer and Eaker (2004) use the text as a model to analyze strategies by union representatives and management in studying a union organizing campaign. In a discussion of the conflict between workers and management at Staley Control, Cloud (2005) refers the reader to the second edition of The Rhetoric of Agitation and Control for a discussion of how each stage of a social movement requires a different balance of material and rhetorical form.

In a rhetorical analysis of Bryant's Cross of Gold speech, Harpine refers to the concept of polarization in the second edition of The Rhetoric of Agitation and Control. Frentz and Rushing (1978) refer the reader to The Rhetoric of Agitation and Control for a description of strategies that those in control may employ. In their analysis of Bush's 1988 presidential campaign, Smith and Smith (1994) refer to the text in their discussion of the use of polarization and derogatory jargon to characterize the "out" group. Gunn, in studying discourse control in plant closings, refers to The Rhetoric of Agitation and Control as a "seminal work" which "illuminates discourse tactics that are used in the agitator/controller/ relationship" and specifically discusses the use of silence as a tactic in her study (2011, 33).

The text is also cited as an example of where to find further explanations of a concept or support for a statement made by an author. These suggestions are usually in an extended footnote or endnote. For example, Stewart (1997) refers readers to the second edition of the text for an analysis of how Abbie Hoffman and Jerry Rubin and their protest organization, the Youth International Party (Yippies) transformed the 1960 peace movement. Ono and Sloop (1995) use the text as an example of post-6os studies of black power. Warnick (1992) refers to the text as one example to demonstrate the use of nonverbal and other sorts of artifacts for rhetorical analysis.

The Rhetoric of Agitation and Control has been used also to stimulate theoretical development in the field as Gronbeck discusses in his paper. In Communication and Negotiation (1992), Putnam and Roloff credit 
The Rhetoric of Agitation and Control as one of the rhetorical studies on persuasion and social conflicts that paved the way for communication scholars to develop a distinct approach to conflict.

According to Goldzwig (1999), the theories described in The Rhetoric of Agitation and Control moved students and scholars beyond a consideration of the usual discursive means of persuasion by including non-discursive elements such as media, music, song, film, and nonverbal cues. This approach has continued in both the second and third editions. Examples of its impact are evident in Irvine and Kirkpatrick's article analyzing music as a rhetorical form (1972) in its reference to The Rhetoric of Agitation and Control for an analysis of how lyrical structure can produce a rhetorical impact. Carter (1980) also refers to the text's analysis of the use of song as a tactic of solidification in movements. Stewart, Smith and Denton (1984) refer to the The Rhetoric of Agitation and Control in their chapter on the persuasive function of symbols, noticeably the use of slogans by agitators, such as "Hey, Hey, LBJ, how many kids have you killed today" (an anti-Vietnam War chant) and their discussion of how opposition, particularly established organizations, cannot take these threats lightly. Teo Peter (2004) also refers to The Rhetoric of Agitation and Control's discussion of slogans as imperative statements as the starting point for his analysis of the Clean and Green Week campaign in Singapore.

In a review of rhetorical studies, Cyphert describes Bowers and Oak's claim that the scope of rhetoric includes all manner of symbolic performance as "leading to some of the most theoretically important discussions of the $20^{\text {th }}$ century" $(2010,354)$. Examples of these discussions continue in the works of Michael McGee (1975) as to what constitutes a movement analysis; the range of confrontational rhetoric (Murphy, 1992); the concept of criticism as organic rather than a dichotomy (Stewart, Smith and Denton, 1984; Darsey, 1991); the function of slogans in movements (Steward, Smith and Denton, 1984); or the instrumentality of nonverbal messages (Enck-Wanzer, 2006).

The Rhetoric of Agitation and Control has stood the test of time. The original edition of the text was written in a time of emerging developments in rhetorical theory and also one of great social activism as evident in campus unrest, Vietnam protest, and the civil rights and women's movements. The book filled a need then and continues to do so today. Over forty years it has made an impact on the field of communication and related fields as evident by the range of journals and number of texts in which references to it appear and in the wide range of social movements to which it has been applied. Furthermore, with each edition citations to The Rhetoric of Agitation and Control have increased as scholars continue to use it as a model for analysis and look to it for insight in the study of social movements and to stimulate theoretical discussion and theory development. 


\section{List of References}

Borchers, T. 2002. Persuasion In The Media Age. New York: McGrawHill Higher Education.

Carter, D. 1980. The industrial workers of the world and the rhetoric of song. Quarterly Journal of Speech, 66, 365-74.

Cloud, D. 2005. Fighting words: Labor and limits of communication at Staley, 1993-1996. Management Communication Quarterly, 18:4, 509-42.

Cyphert, D. 2010. The rhetorical analysis of business speech: unresolved questions. Journal of Business Communication, 47:3, 346-368.

Darsey, J. 1991. From 'Gay is Good' to the scourge of AIDS: The evolution of gay liberation rhetoric, 1977-1990. Communication Studies, 42, 4366.

Enck-Wanzer, D. 2006. Trashing the system: Social movement, intersectional rhetoric, and collective agency in the Young Lords organization's garbage offensive. Quarterly Journal of Speech, 92:2, 174-201.

Frentz, T. and Rushing, J. 1978. The rhetoric of 'Rocky': Part two. Western Journal of Speech, 42, 231-240.

Frey, L., Botan, C. and Kreps, G. 2000. Investigating Communication: An Introduction To Research Methods. Second ed. Needham Heights, MA: Allyn \& Bacon.

Goldzwig, S. 1999. Civil Rights in the postmodern era: An introduction. Rhetoric and Public Affairs, 2:2, 171-176.

Gunn, A. 2011. Discourses that silence and deflect attention away from the interests of low-wage workers experiencing job loss. Critical Discourse Studies, 8:1, 31-44.

Harpine, W. 2001. Bryan's 'A Cross of Gold:' The rhetoric of polarization at the 1896 Democratic Convention. Quarterly Journal of Speech, 87:3, 291-304.

Irvine, J. and Kirkpatrick, W. 1972. The musical form in rhetorical exchange: Theoretical considerations. Quarterly Journal of Speech, $58,272-84$.

McGee, M. 1972. In search of 'The People': A rhetorical alternative. Quarterly Journal of Speech, 61:3, 235-48.

Murphy, J. 1992. Domesticating dissent: The Kennedys and the freedom rides. Communication Monographs, 59, 61-78.

Ono, K. and Sloop, J. 1995. The critique of vernacular discourse. Communication Monographs, 62, 19-46.

Peter, T. 2001. 'Clean and green - That's the way we like it': Greening a country, building a nation. Journal of Language and Politics, 3:3, 485-505. 
Rubin, J., Pruitt, D., and Kim, S. H.. 1994. Social Conflict: Escalation, Stalemate And Settlement. McGraw Hill: New York.

Saunders, M. 2004. Patterns of conflict preceding a crisis: A case study analysis. In Dan Millar and Robert Heath, eds., Responding To Crisis: A Rhetorical Approach To Crisis Communication. Mahwah, New Jersey: Lawrence Erlbaum Associates.

Smith, C. and Smith, K. 1994. The White House Speaks: Presidential Leadership As Persuasion. Praeger Publishers: Westport, CT.

Stewart, C. 1997. The evolution of a revolution: Stokely Carmichael and the rhetoric of Black Power. Quarterly Journal of Speech, 83, 429446.

Stewart, C., Smith, C., and Denton, R. 1984. Persuasion And Social Movements. Prospect Heights, IL: Waveland Press.

Warnick, B. 1992 Leff in context: What is the critic's role? Quarterly Journal of Speech, 78, 232-237. 